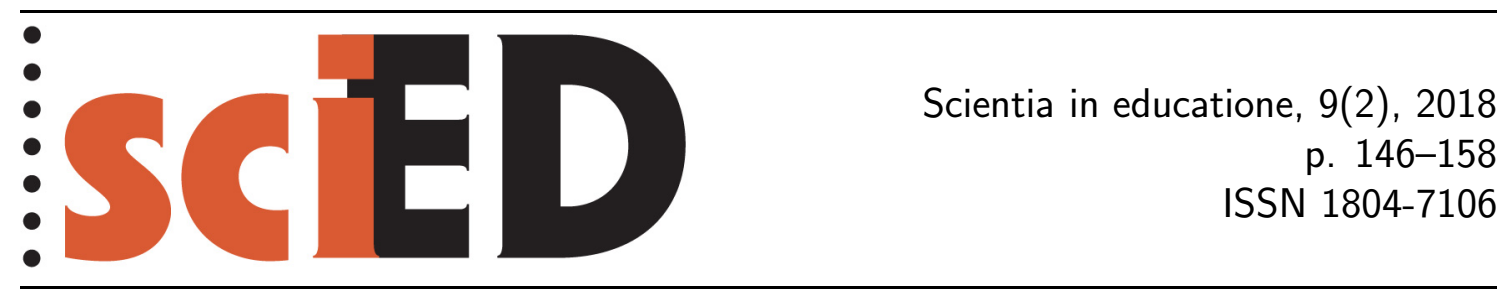

\title{
Developing Prospective Mathematics Teachers' Knowledge of the Modelling Approach
}

\author{
Juhaina Awawdeh Shahbari, Michal Tabach
}

\begin{abstract}
Modelling is considered an important approach that requires prospective teachers to be qualified both in modelling competencies and in pedagogical knowledge. In order to investigate the development of these competencies, we examined 49 prospective mathematics teachers studying in a course that included a sequence of modelling activities. During the course, groups of 5-6 participants engaged in these modelling activities as learners. The data include two sets of reports by the prospective teachers on their observations of a recorded modelling activity carried out by a group of five $6^{\text {th }}$ grade students. The first set of reports was collected before the prospective teachers worked on any modelling activities, while the second set was collected after they had engaged in the modelling activities. The findings indicate that, prior to working on modelling activities, most of the prospective teachers described the students' modelling activity as a linear process and focused on the final mathematical model and the mathematical results. After the prospective teachers engaged in the activities, most of their reports identified cyclical processes as the mathematical models progressed.
\end{abstract}

Key words: modelling, modelling abilities/competencies, modelling process, prospective teachers.

\section{Rozvoj znalostí o modelování u budoucích učitelů matematiky}

\begin{abstract}
Abstrakt
Modelování je považováno za důležitý př́stup k vyučování, jenž vyžaduje, aby byli budoucí učitelé dostatečně kvalifikováni jak v samotném modelování, tak i v jeho didaktice. Abychom prozkoumali možný rozvoj těchto kompetencí, provedli jsme výzkum u 49 budoucích učitelů matematiky, kteří se účastnili kurzu, zahrnujícího sérii aktivit na modelování. V průběhu kurzu se do těchto aktivit zapojovaly skupiny po 5 až 6 účastnících. Výzkumná data zahrnují dvě zprávy, které vypracovali budoucí učitelé poté, co shlédli na záznamu skupinu pěti žáků 6. ročníku, jak se zabývají modelováním. První zpráva byla vypracována před tím, než se budoucí učitelé sami zapojili do modelovacích činností, druhá poté, co sami získali s modelováním zkušenosti. Výsledky ukazují, že před vlastním zapojením do modelovacích aktivit budoucí učitelé popisovali modelování u žáků jako lineární proces a zaměřovali se na výsledný matematický model a matematické výsledky. Po vlastním zapojení do modelovacích činností byla většina $\mathrm{z}$ budoucích učitelů schopna rozeznat cyklické procesy, pomocí nichž se matematické modely vyvíjely.
\end{abstract}

Klíčová slova: modelování, schopnost modelovat, proces modelování, budoucí učitelé. 
The modelling approach to teaching and learning mathematics emphasizes the effectiveness of mathematics in real life (Vorhölter, Kaiser \& Borromeo Ferri, 2014) along with the students' need for knowledge and competencies to deal with complex systems and real world situations (English \& Sriraman, 2010; Lesh \& Doerr, 2003). With respect to the education of mathematics teachers, the modelling approach posits that expertise in teaching should be reflected in what teachers can "do" and what they "see" in teaching, learning, and problem-solving situations (Lesh \& Lehrer, 2003: p. 111), so that their interventions while their students engage in modelling activities will be effective (Blum \& Leiß, 2005). Several studies (e.g., Cetinkaya et al., 2016) have reported barriers and difficulties among prospective teachers that were related to the teaching and learning of modelling. Thus, it is important to develop modelling competencies and knowledge (Tan \& Ang, 2013). To meet this requirement, researchers have proposed modelling courses for prospective teachers (e.g., Borromeo Ferri \& Blum, 2010; Kaiser \& Schwarz, 2006).

The current study joins previous studies by suggesting that prospective teachers should gain experience in modelling sequences. Our aim in this paper is to examine changes in the ability of prospective teachers to identify their students' modelling processes. We adopted the modelling cycle of Blum and Leiß (2005) as a visual aid to examine changes in identified students' modelling cycles and processes.

\section{THEORETICAL BACKGROUND}

\section{ModelLing}

Mathematical modelling is defined as solving real-world problems with the help of mathematics (Mischo \& Maaß, 2013). Modelling activities involve partial, ambiguous or undefined information about a situation (English \& Fox, 2005). During these activities, learners need to mathematize in ways that are meaningful to them while they work in small groups (English \& Watters, 2004). This involves a cyclic process of translation, description, explanation, justification and prediction of data outcomes (Lesh \& Doerr, 2003). Several researchers (e.g., Doerr \& English, 2003) identified the modelling process and described it verbally, without visual description of the modelling cycles. While various visual descriptions have been suggested by different researchers (e.g., Blum \& Leiß, 2005; Geiger, 2011), in the current study we adopted the modelling cycle proposed by Blum and Leiß (2005), which appears often in the literature (Stohlmann et al., 2016: p. 13). This cycle includes phases and actions that lead from one phase to another. The phases consist of a situation model, a real model, a mathematical model, mathematical results and realistic results. The actions include the following: i) understanding the problem and simplifying a situation model; ii) presenting a real model; iii) mathematizing, which leads to constructing a mathematical model; iv) applying mathematical procedures that yield mathematical results; v) interpreting these mathematical results with respect to the real-world situation; and vi) validating these results with reference to the situation. If the outcomes do not satisfy the needs of the original situation, the cycle begins again. In order to carry out modelling processes effectively, modellers need mathematical and communicational competencies, which are referred to as modelling abilities or competencies (English \& Fox, 2005). Modelling competencies are "skills and abilities to perform modelling processes appropriately and goal-oriented, 
as well as the willingness to put these into action" (Maaß, 2006: p. 117). Modelling competencies are needed to complete modelling activities successfully (Stillman et al., 2007). According to Maaß (2006), there is a consensus that modelling competencies include certain sub-competencies, among them recognizing relevant variables, constructing relations between variables, choosing appropriate mathematical notations, selecting and applying appropriate formulae and generalizing or extending the solution.

\section{EDUCATING TEACHERS FOR MODELLING ACTIVITIES}

One of the barriers to effective application of modelling activities in the classroom is the limited nature of teachers' subject-specific and pedagogical knowledge about modelling (Kuntze, Siller \& Vogl, 2013). Therefore, the prospective teachers' qualifications vis-à-vis modelling activities are considered an important issue that has been addressed in various studies (e.g., Borromeo-Ferri \& Blum, 2010; Cetinkaya et al., 2016). Different types of courses for prospective teachers have been suggested, such as a course integrating theory and practice as suggested by Borromeo-Ferri and Blum (2010). This course offers integration by focusing on theories about modelling, solving and designing modelling problems, analysing students' modelling processes and discussing the role of teachers while their students solve modelling activities. Stender and Kaiser (2015) adopted a different perspective. They proposed training prospective teachers by focusing on scaffolding. They reported that the training they conducted within the seminar for prospective teachers was successful in terms of the students' preference for using scaffolds that promote independent student modelling activities. Another type of course that integrated modelling with technology was designed by Lingefjärd and Holmquist (2001). In this course the prospective teachers were asked to solve modelling activities by using technology and their own mathematical knowledge. In addition, the course emphasized the validation phase in the modelling process.

Along the same lines, several other studies have also noted that engaging in modelling activities has positive effects for prospective teachers. These include developing their ideas about the nature of modelling and modelling tasks (Cetinkaya et al., 2016); changing their beliefs concerning mathematics from static views to more application-oriented views (Kaiser \& Schwarz, 2006); influencing their ability to construct modelling activities while considering different principles (Bukova-Güzel, 2011); having an impact on their knowledge, skills, and opinions regarding mathematical modelling (Ciltas \& Isik, 2013); and affecting their pedagogical content knowledge about mathematical modelling and their self-efficacy in modelling (Maaß \& Gurlitt, 2011).

\section{RESEARCH QUESTIONS}

The current study sought to address the effect of engagement in sequences of modelling activities among prospective teachers by focusing on their ability to interpret student modelling activities. More specifically, this research addresses the following questions:

1. How do prospective mathematics teachers with no prior modelling experience interpret students' modelling activity? 
2. Does participation in a sequence of modelling activities change how prospective mathematics teachers interpret students' modelling activity? If yes, to what extent?

\section{METHODOLOGY}

\section{PARTICIPANTS}

The study was conducted among 49 prospective teachers in their second year of studies in the primary mathematics education track at a college of education in Israel. As part of their studies, participants took a problem-solving course taught by the first author. During this course, the participants engaged in a sequence of modelling activities (more details are provided in the section describing the sequence of modelling activities). None of them had any previous experience with modelling.

\section{PROCEDURE AND DATA SOURCES}

The prospective teachers were given a 70-minute-long video recording and transcript that documented five $6^{\text {th }}$ grade students working on a modelling activity (the sneaker activity, taken from Doerr \& English, 2003, see appendix A). After watching the video, they each wrote an initial report (R1) about the students' work on the modelling activity. After submitting R1, groups of five to six prospective teachers worked on four modelling activities. The work on each of the four modelling activities took place once a week for approximately 90 minutes. The participants then watched the same video again and wrote a second report (R2) about the students' work on the activity. In total, two sets of 26 reports were submitted. Eight weeks elapsed between R1 and R2.

\section{SEQUENCE OF MODELLING ACTIVITIES}

The prospective teachers worked on a sequence that included four modelling activities designed by the researchers. The camp activity (Shahbari \& Tabach, 2017) was presented via four tables that provided information about six camps, with each table referring to several components. The first table included the dates of each camp, as well as information on transportation, food and costs. The second table included types and numbers of entertainment activities at each camp. The third table consisted of data from the previous year about the number of participants and number of counsellors at each camp. The fourth table contained the parents' evaluations and rankings of the camps from the previous year, with the rankings ranging from one to five stars.

The good teacher activity (Shahbari \& Tabach, 2017, see appendix B) also comprised four tables describing ten candidates for a teaching position. The first table included the candidates' ages and their average grades in their B.Ed. studies. The second table included the candidates' rankings by their pedagogical instructors for their practicum work in the schools over three years, with the rankings ranging from $\mathrm{A}+$ to $\mathrm{F}$. The third table included the rankings of the candidates' performance at an interview, with the rankings ranging from "not at all acceptable" to "widely acceptable". The fourth table included the candidates' rankings on social initiatives, ranging from "did not participate at all" to "participated to a large extent". 
For both the camp activity and the good teacher activity, the prospective teachers were required to write a letter explaining their choice of suitable of camps/candidates and to propose a model for choosing suitable camps/candidates that can be used in the coming years.

The flower activity concerned an art teacher planning to recreate a picture of a flower (the image of the flower is given) with the participation of all 524 students in the school. In the re-creation the students would be required to wear yellow, green, or brown clothing in accordance with the original picture and their position in the recreated image. The prospective teachers were requested to write a letter to this art teacher explaining how to enlarge the picture so that all the students could participate, how to position the students in the schoolyard, and how many students should be wearing clothes of each colour (yellow, green and brown).

Finally, in the toothpaste activity (Shahbari \& Tabach, 2016a) the prospective teachers were told that the opening of their toothpaste tube had been enlarged, and they were asked to write a letter describing how their consumption of toothpaste had changed using this tube compared to the original tube.

We designed the four activities in order to expose the participants to different types of modelling activities. The first two activities are classified as model-eliciting activities and the last two as authentic modelling activities, according to the classification of modelling activities by Kaiser and Schwarz (2006). The two model-eliciting activities are designed based on the six principles outlined by Lesh et al. (2000).

\section{DATA ANALYSES}

\section{RESEARCHERS' ANALYSES OF STUDENT MODELLING IN THE sneaker ACTIVITY}

The work of a group of five $6^{\text {th }}$ grade students on the sneaker activity was videorecorded. The researchers analysed the students' solution path in the video-recording of the sneaker activity according to the modelling cycle of Blum and Leiß (2005) and described the analyses visually (Shahbari \& Tabach, 2017 - see Figure 1). The analyses indicated that the students' solution included three modelling cycles. The numbers in Figure 1 indicate modelling actions $[1=$ understanding and simplifying; $2=$ mathematizing; $3=$ applying; $4=$ interpreting the mathematical results; $5=$ validating]. The letters indicate the modelling phases $[\mathrm{A}=$ real model; $\mathrm{B}=$ mathematical model; $\mathrm{C}=$ mathematical results; $\mathrm{D}=$ realistic results]. The combinations of letters and numbers indicate the number of the modelling cycle in each phase.

Fig. 1: Researchers' analyses of the solution path of the $6^{\text {th }}$ grade students' activity (Shahbari \& Tabach, 2017)

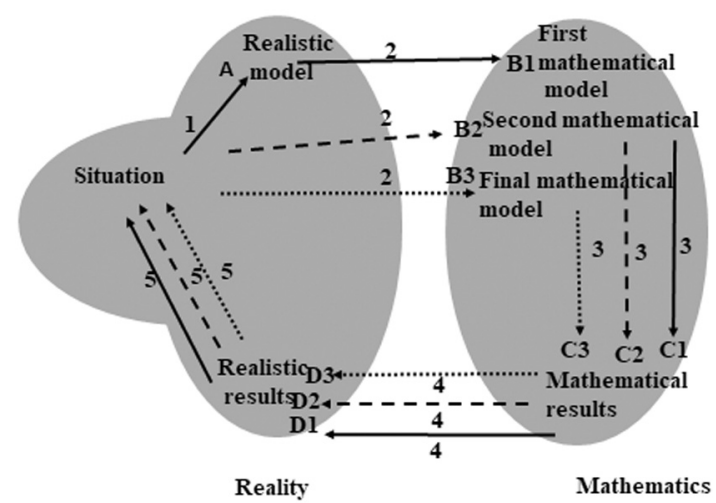




\section{REPORT ANALYSES}

We examined the two sets of the prospective teachers' reports (R1 and R2) to see whether references were made to each of the modelling phases $(A-D)$ and modelling actions (1-5). Next we compared each report with the one produced by the researchers' analyses, as reflected in Fig. 1. We represented each report visually to facilitate identifying changes between the first report set (R1) and the second report set (R2) and to determine to what extent the prospective teachers' reports had changed.

\section{FINDINGS}

\section{DEVELOPING ABILITIES FOR IDENTIFYING MODELLING PROCESSES} IN STUDENTS' MODELLING ACTIVITY

We report the findings according to the prospective teachers' descriptions of the modelling activities and according to their identification of modelling phases and actions in the two reports, R1 and R2. Analyses of the prospective teachers' reports indicated that $\mathrm{R} 1$ can be classified into four categories and R2 into five categories. We described each category visually in Fig. 2, 3, 4, 5, and 6 and Fig. 1 above.

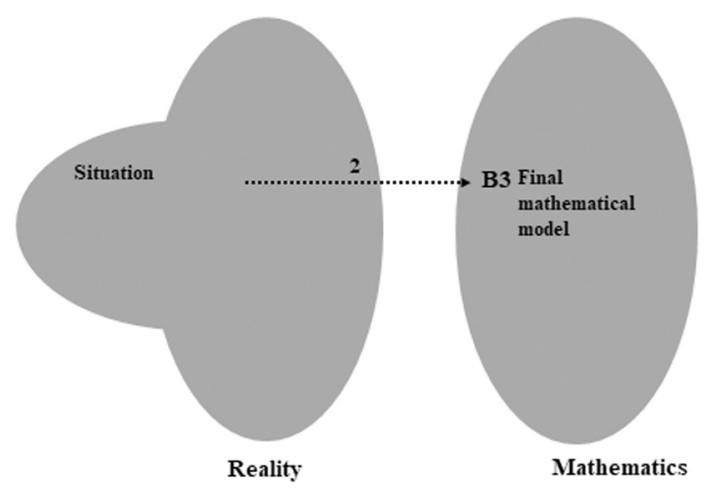

Fig. 2: Frequencies of prospective teachers' descriptions in R1 and R2 (\%): $\mathrm{R} 1=38, \mathrm{R} 2=11$

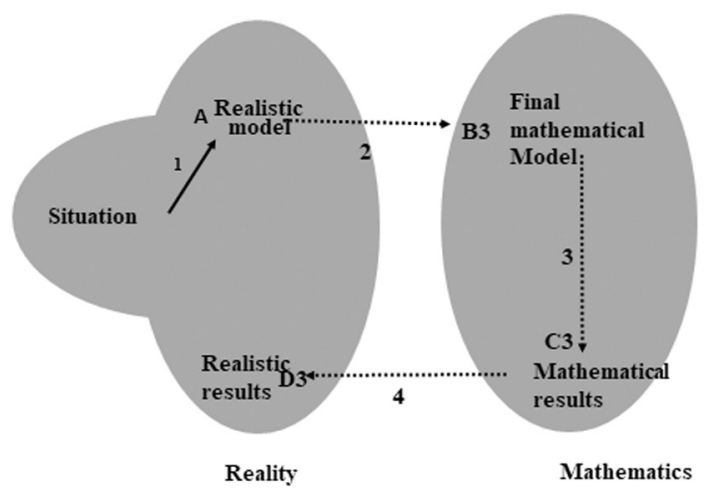

Fig. 4: Frequencies of prospective teachers' descriptions in R1 and R2 (\%): $\mathrm{R} 1=12, \mathrm{R} 2=31$

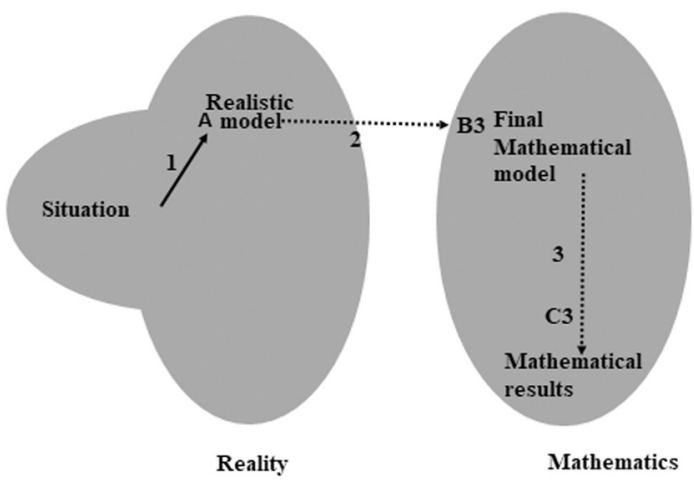

Fig. 3: Frequencies of prospective teachers' descriptions in R1 and R2 (\%): $\mathrm{R} 1=46, \mathrm{R} 2=27$

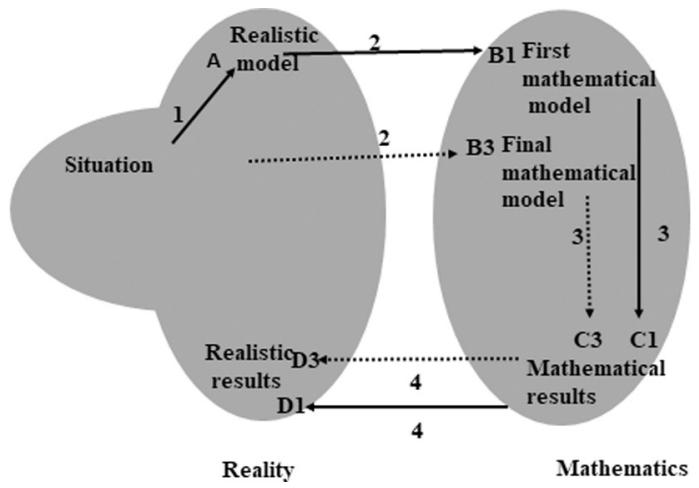

Fig. 5: Frequencies of prospective teachers' descriptions in R1 and R2 (\%): $\mathrm{R} 1=4, \mathrm{R} 2=-$ 
Fig. 6: Frequencies of prospective teachers' descriptions in R1 and R2 (\%): $\mathrm{R} 1=-, \mathrm{R} 2=12$

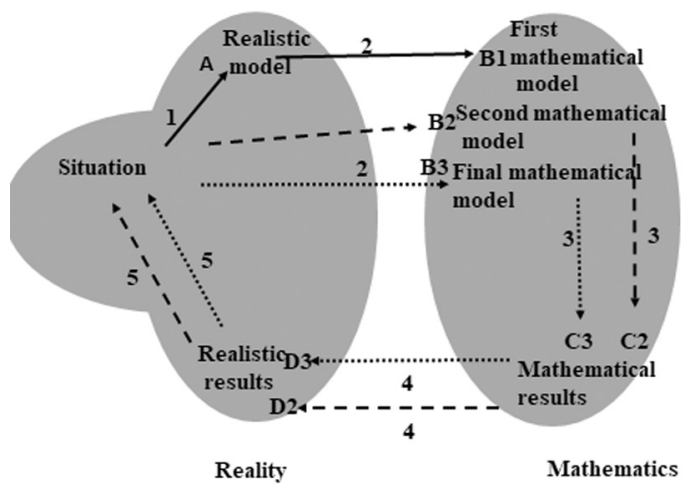

Similar to researchers' analysis (see Fig. 1) $\mathrm{R} 1=-, \mathrm{R} 2=19$.

In the following section, we briefly explain each figure 2-6. Figure 2 considers only the mathematizing action and the final mathematical model (B3), while ignoring all the other modelling phases and actions. Figure 3 includes interpretation of the situation, describes the real model (A), considers the mathematical work and the final mathematical model (B3), and describes the mathematical results (C3) elicited by applying the final mathematical model. Figure 4 considers all the phases and actions appearing in Figure 3, in addition to the realistic results (D3) obtained from interpreting the mathematical results to reality. Figure 5 considers the first model cycle as in Figure 4 and also considers the third cycle, including the mathematical work, the third mathematical model (B3), the mathematical results (C3) obtained from applying these models and the realistic results (D3). Figure 6 considers part of the first modelling cycle and all the phases and actions of the second and third modelling cycles.

In general, only one R1 noted two modelling cycles. The other R1s identified only one modelling cycle, while a third of the R2s identified three modelling cycles. More than half of the prospective teachers' $\mathrm{R} 1 \mathrm{~s}$ considered the mathematical results of applying the final model. In addition, in the R1s little attention was devoted to the modelling phases or to actions related to the first two modelling cycles. In contrast, the descriptions in the R2s paid attention to the three modelling cycles in relation to the modelling phases and actions in them. The results also show that both in the $\mathrm{R} 1 \mathrm{~s}$ and in the R2s, the least amount of attention was directed toward validating processes in three modelling cycles compared with other actions. Figures 7 and 8 summarize the phases and actions identified by the prospective teachers in the two reports.

\section{DISCUSSION}

The first research question examined how prospective mathematics teachers with no prior modelling experience interpret students' modelling activity. The findings indicate that before the prospective teachers engaged in modelling activities themselves, their descriptions did not include the entire modelling process. Most of the R1 descriptions considered the final mathematical model and the mathematical results of applying this model, while overlooking the realistic results and the validating process. In addition, most R1 descriptions disregarded the second and third mathematical modelling cycles as well as the modelling phases and actions related to these cycles. The prospective teachers placed emphasis on the final model without considering the first and second model cycles, implying that they considered the 

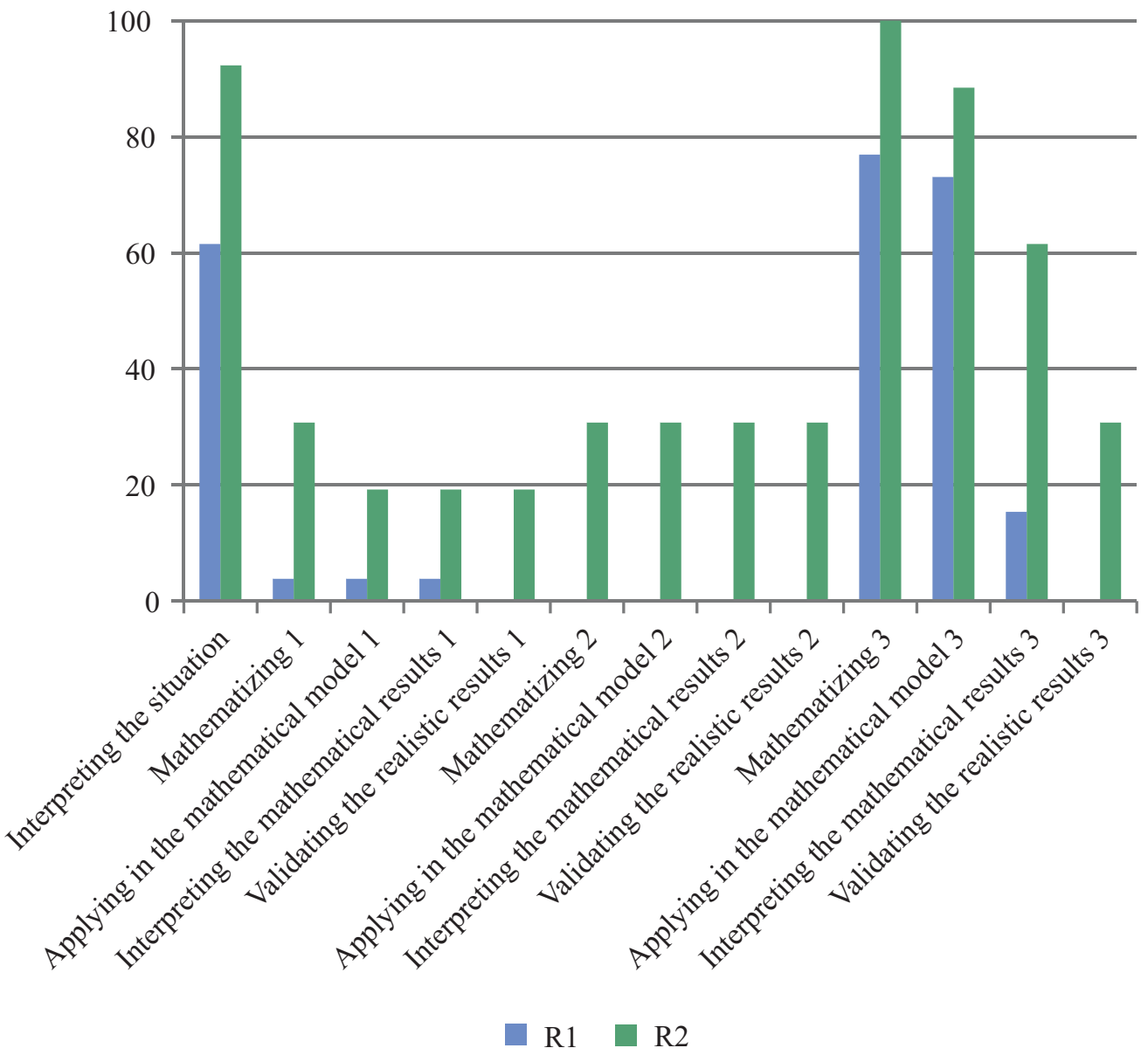

Fig. 7: Modelling phases identified in the two reports

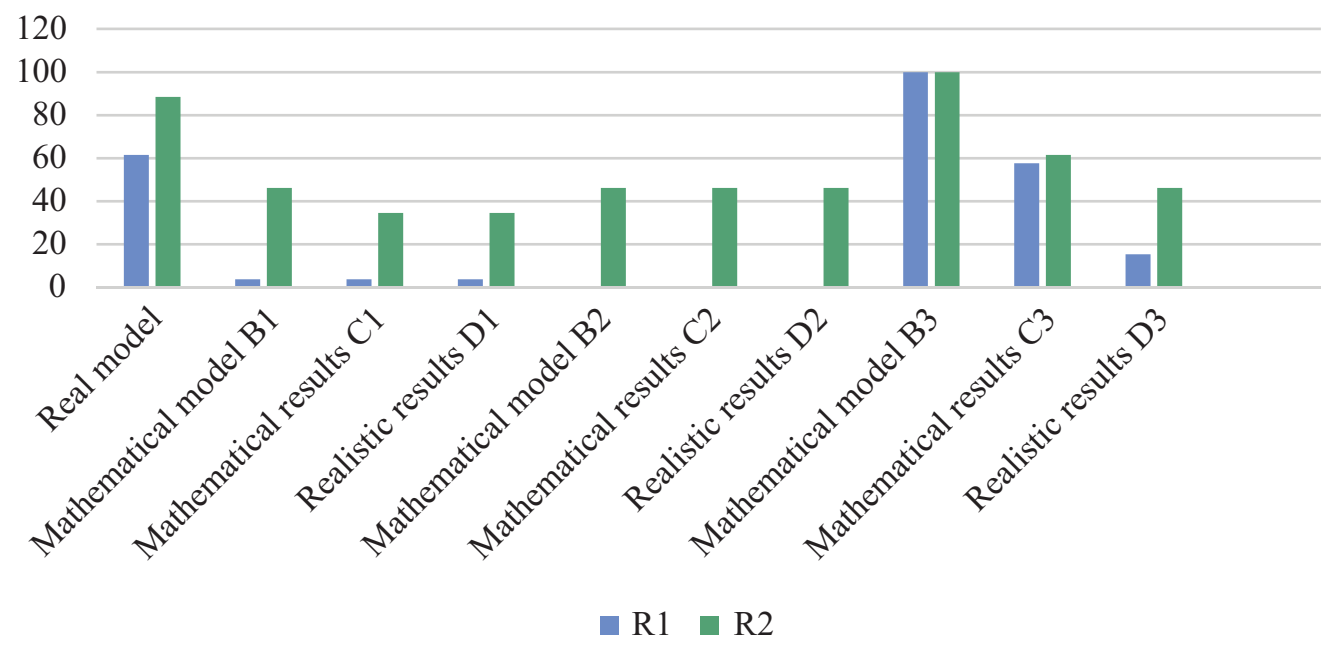

Fig. 8: Modelling actions identified in the two reports

solution path to be linear. In other words, the prospective teachers expected to see a specific computational solution rather than a more general strategy, as outlined in Doerr and English (2006). Furthermore, it is possible that the prospective teachers emphasized the final mathematical model because they were expecting it to be the result of the students' work.

Now we consider whether participation in a sequence of modelling activities changed the ways in which prospective teachers interpret students' modelling activity, and if so, then to what extent. The findings indicated that prospective teachers' 
active participation in the modelling activities made them more aware of the processes according to which mathematical models progress. The findings obtained from analysing the R2s indicate that more prospective teachers considered the three modelling cycles and took the cyclic process of the mathematical models' progress into consideration. In the R2s, the actions (understanding and simplifying, mathematizing, applying, interpreting the mathematical results, validating) and the phases (real model, first and second mathematical model, mathematical results, realistic results) were more frequently identified than in the R1s. These results are in line with those of Tan and Ang (2013), who reported that knowledge of different elements in modelling process phases was enhanced by experience with modelling activities. A stronger influence of experience with modelling activities was found among practicing teachers (Shahbari \& Tabach, 2016b). Our findings in the current study show that in both reports the participants made the fewest references to the validating process. It is important to note that validation is considered to be the most difficult process for learners in dealing with modelling activities because in "regular" classroom activity it is the teacher who is responsible for solution correctness (Blum \& Borromeo Ferri, 2009).

Based on the findings of this study, we recommend providing opportunities for prospective teachers to deal with modelling activities as learners. We also recommend adopting the modelling cycle to monitor their pedagogical knowledge as expressed in their ability to interpret students' modelling activities.

\section{REFERENCES}

Blum, W. \& Borromeo Ferri, R. (2009). Mathematical modelling: Can it be taught and learnt? Journal of mathematical modelling and application, 1(1), 45-58.

Blum, W. \& Leib, D. (2005). "Filling Up" - the problem of independence - preserving teacher interventions in lessons with demanding modelling tasks. In M. Bosch (Ed.), CERME 4-Proceedings of the Fourth Congress of the European Society for Research in Mathematics Education (1623-1633). Sant Feliu de Guíxols, Spain: ERME.

Borromeo Ferri, R. \& Blum, W. (2010). Mathematical modelling in teacher education experiences from a modelling seminar. In V. Durand-Guerrier, S. Soury-Lavergne \& F. Arzarello (Eds.), CERME 6, Proceedings of the sixth congress of the European Society for Research in Mathematics Education (2046-2055). Lyon: Institut national de recherche pédagogique.

Bukova-Güzel, E. (2011). An examination of pre-service mathematics teachers' approaches to construct and solve mathematical modelling problems. Teaching Mathematics and its Applications: An International Journal of the IMA, 30(1), 19-36.

Cetinkaya, B., Kertil, M., Erbas, A. K., Korkmaz, H., Alacaci, C. \& Cakiroglu, E. (2016). Pre-service teachers' developing conceptions about the nature and pedagogy of mathematical modeling in the context of a mathematical modeling course. Mathematics Thinking Learning, 18(4), 287-314.

Ciltas, A. \& Isik, A. (2013). The effect of instruction through mathematical modelling on modelling skills of prospective elementary mathematics teachers. Educational Sciences: Theory and Practice, 13(2), 1187-1192.

Doerr, H. M. \& English, L. D. (2006). Middle grade teachers' learning through students' engagement with modeling tasks. Journal of Mathematics Teacher Education, 9(1), 5-32. 
Doerr, H. \& English, L. (2003). A modelling perspective on students' mathematical reasoning about data. Journal for Research in Mathematics Education, 34(2), 110-136.

English, L. D. \& Fox, J. L. (2005). Seventh-graders' mathematical modelling on completion of a three-year program. In P. Clarkson et al. (Eds.), Building connections: Theory, research and practice (Vol. 1, 321-328). Melbourne: Deakin University Press.

English, L. D. \& Watters, J. J. (2005). Mathematical modelling in the early school years. Mathematics education research journal, 16(3), 58-79.

English, L. \& Sriraman, B. (2010). Problem solving for the 21st century. In B. Sriraman \& L. English (Eds.), Theories of Mathematics Education: Seeking New Frontiers (263-290). Berlin/Heidelberg: Springer Science and Business.

Geiger, V. (2011). Factors affecting teachers' adoption of innovative practices with technology and mathematical modeling. In G. Kaiser, W. Blum, R. Borromeo Ferri \& G. Stillman (Eds.), Trends in Teaching and Learning of Mathematical Modeling, (ICTMA 14) (305-314). New York: Springer.

Kaiser, G. \& Schwarz, B. (2006). Mathematical modelling as bridge between school and university. $Z D M, 38(2), 196-208$.

Kuntze, S., Siller, H.-S. \& Vogl, C. (2013). Teachers' self-perceptions of their pedagogical content knowledge related to modelling - an empirical study with Austrian teachers. In G. Stillman, G. Kaiser, W. Blum \& J.P. Brown (Eds.), Teaching mathematical modelling: Connecting to research and practice (317-326). Dordrecht, The Netherlands: Springer.

Lesh, R. A. \& Doerr, H. M. (2003). Beyond constructivism: Models and modeling perspectives in mathematics teaching, learning, and problem Ssolving. Mahawah, N.J.: Lawrence Erlbaum.

Lesh, R., Hoover, M., Hole, B., Kelly, A. \& Post, T. (2000). Principles for developing thought-revealing activities for students and teachers. In R. Lesh \& A. Kelly (Eds.), Handbook of research design in mathematics and science education (591-644). Mahwah, NJ: Lawrence Erlbaum.

Lesh, R. \& Lehrer, R. (2003). Models and modelling perspectives on the development of students and teachers. Mathematical Thinking and Learning, 5(2-3), 109-129.

Lingefjard, T. \& Holmquist, M. (2001). Mathematical modelling and technology in teacher education - visions and reality. In J. Matos, S. K. Houston, W. Blum, \& S. Carreira (Eds.), Modelling and mathematics education: Applications in science and technology (205-215). Chichester: Horwood Publishing.

Maaß, K. (2006). What are modelling competencies? ZDM, 38(2), 113-142.

Maaß, K. \& Gurlitt, J. (2011). LEMA-Professional development of teachers in relation to mathematical modeling. In G. Kaiser, W. Blum, R. Borromeo Ferri \& G. Stillman (Eds.), Trends in teaching and learning of mathematical modeling: ICTMA 14 (629-639). New York: Springer.

Mischo, C. \& Maaß, K. (2013). The effect of teacher beliefs on student competence in mathematical modeling - an intervention study. Journal of Education and Training Studies, 1(1), 19-38.

Shahbari, J. A. \& Tabach, M. (2016a). Different generality levels in the product of a modelling activity. In C. Csikos, A. Rausch \& J. Szitanyi (Eds.), Proceedings of the $40^{\text {th }}$ Conference of the International Group for the Psychology of Mathematics Education (Vol. 4, 179-186). Szeged, Hungary: PME. 
Shahbari, J. A. \& Tabach, M. (2016b). Developing modelling lenses among practicing teachers. International Journal of Mathematical Education in Science and Technology, 47(5), 717-732.

Shahbari, J. A. \& Tabach, M. (2017). The commognitive framework lens to identify the development of modelling routines. In B. Kaur, W. Kin Ho, B. Heng Choy (Eds.), Proceedings of the $4^{\text {th }}$ Conference of the International Group for the Psychology of Mathematics Education (Vol. 4, 185-192). Singapore, Singapore: PME.

Stender, P. \& Kaiser, G. (2015). Scaffolding in complex modelling situations. ZDM, $47(7), 1255-1267$.

Stillman, G., Galbraith, P., Brown, J. \& Edwards, I. (2007). A framework for success in implementing mathematical modelling in the secondary classroom. In J. Watson \& K. Beswick (Eds.), Proceedings of the 30th Mathematics Education Research Group of Australasia conference Mathematics: Essential research, essential practice (Vol. 2, 688-707). Adelaide: MERGA.

Stohlmann, M., DeVaul, L., Allen, C., Adkins, A., Ito, T., Lockett, D. \& Wong, N. (2016). What is known about secondary grades mathematical modelling - A Review. Journal of Mathematics Research, 8(5), 12.

Tan, L. S. \& Ang, K. C. (2013). Pre-service secondary school teachers knowledge in mathematical modelling - A case study. In G. Stillman, G. Kaiser, W. Blum \& J. Brown (Eds.), Teaching mathematical modelling: Connecting research to practice (373-384).

New York: Springer.

Vorhölter, K., Kaiser, G. \& Borromeo Ferri, R. (2014). Modelling in mathematics classroom instruction: An innovative approach for transforming mathematics education. In Y. Li, E. A. Silver \& S. Li (Eds.), Transforming Mathematics Instruction (21-36). Cham, Switzerland: Springer.

JuHAINA AWAWDEH ShahBARI, juhaina8@gmail.com Al-Qasemi Academy \& The College of Sakhnin, Israel

Michal TABACH, tabachm@post.tau.ac.il

Tel-Aviv University, Israel

\section{APPENDIX A}

Sneaker problem (Doerr \& English, 2003): Students encounter the notion of multiple factors that can be used in developing a rating system for purchasing sneakers and the notion that not all factors are equally important to all people. Students were asked: "What factors are important to you in buying a pair of sneakers?" This generated a list of factors in which not all the factors were equally important to the students. The students then worked in small groups to determine how to rank these factors in deciding which pair of sneakers to purchase. 


\section{Appendix B}

The good teacher activity:

Mr. Salama is a principal of an elementary school that is sponsored by a teachers training college. He is seeking a candidate for the position of math teacher at his school. The college sent him a list of graduates who completed a B.Ed. in elementary mathematics during the last year, as described in Tab. 1.

Tab. 1: Candidates' ages and average grades in their B.Ed. studies

\begin{tabular}{|l|c|c|}
\hline Name & Age & $\begin{array}{c}\text { Average grades } \\
\text { in B.Ed. studies }\end{array}$ \\
\hline Rawan & 23 & 95 \\
\hline Sereen & 21 & 82 \\
\hline Adeam & 22 & 85 \\
\hline Nemreen & 24 & 91 \\
\hline Jawan & 25 & 96 \\
\hline Wafaa & 32 & 78 \\
\hline Aram & 27 & 82 \\
\hline Mayar & 26 & 84 \\
\hline Maysan & 25 & 92 \\
\hline Nasreen & 29 & 90 \\
\hline
\end{tabular}

Mr. Salama decided he needed more details about how the pedagogical instructors ranked the candidates' practice teaching. He asked the pedagogical instructors who had worked with the candidates over the past three years for comments on specific components. The pedagogical instructors assessed the candidates using the following grades, as shown in Table 2 below: $\mathrm{A}+, \mathrm{A}, \mathrm{B}+, \mathrm{B}, \mathrm{C}+, \mathrm{C}, \mathrm{D}+, \mathrm{D}, \mathrm{E}+, \mathrm{E}$, $\mathrm{F}+, \mathrm{F}$.

\begin{tabular}{|c|c|c|c|c|c|c|c|c|c|c|c|c|c|c|c|}
\hline \multirow[t]{2}{*}{ Name } & \multicolumn{3}{|c|}{$\begin{array}{l}\text { Took student } \\
\text { diversity into } \\
\text { consideration }\end{array}$} & \multicolumn{3}{|c|}{$\begin{array}{l}\text { Able to work } \\
\text { in a team }\end{array}$} & \multicolumn{3}{|c|}{$\begin{array}{c}\begin{array}{c}\text { Preparation } \\
\text { of teaching } \\
\text { materials }\end{array} \\
\end{array}$} & \multicolumn{3}{|c|}{$\begin{array}{c}\text { Classroom } \\
\text { management }\end{array}$} & \multicolumn{3}{|c|}{$\begin{array}{c}\text { Mastery } \\
\text { of elementary } \\
\text { school contents } \\
\end{array}$} \\
\hline & $\begin{array}{l}\text { st } \\
\text { year }\end{array}$ & & & & & & & & & & & & $\begin{array}{c}1 \text { st } \\
\text { year }\end{array}$ & & \\
\hline & $\frac{7}{5}$ & & $\mathrm{D}+$ & $\bar{F}$ & & + & + & & $\mathrm{C}+$ & $\overline{\mathrm{D}}$ & & + & A & $\mathrm{A}$ & $\overline{\mathrm{A}+}$ \\
\hline & C & & $\mathrm{B}+$ & $\mathrm{E}$ & + & $\mathrm{A}$ & $\mathrm{D}+$ & $\mathrm{E}+$ & $\mathrm{C}$ & $\mathrm{B}+$ & B & $\mathrm{A}$ & $\mathrm{C}$ & $\mathrm{C}+$ & $\overline{A+}$ \\
\hline & & & $\bar{A}$ & & & & + & 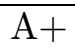 & $\mathrm{A}$ & $\mathrm{A}$ & & & $3+$ & $\bar{A}$ & $\overline{\mathrm{A}}$ \\
\hline en & + & + & + & $\mathrm{E}+$ & + & + & $\mathrm{E}+$ & $\mathrm{D}+$ & $\mathrm{C}+$ & $\mathrm{C}+$ & D & $\overline{\mathrm{B}+}$ & $\mathrm{E}+$ & $\mathrm{C}+$ & $\overline{\mathrm{A}+}$ \\
\hline awa & $\mathrm{B}+$ & $\bar{A}$ & $\bar{A}$ & $\mathrm{~F}+$ & $\mathrm{F}+$ & $\mathrm{C}+$ & $\mathrm{B}+$ & $\bar{A}$ & $\mathrm{~A}+$ & $\mathrm{F}+$ & $\mathrm{D}+$ & $\mathrm{C}$ & B & $\mathrm{B}+$ & $\mathrm{A}$ \\
\hline Waf: & $\mathrm{F}+$ & + & $\mathrm{B}+$ & $\mathrm{B}+$ & $\mathrm{A}+$ & $\mathrm{F}+$ & $\mathrm{C}+$ & $\mathrm{B}$ & $\mathrm{A}$ & $\mathrm{x}+$ & $\mathrm{B}+$ & A & $\mathrm{B}+$ & + & $\mathrm{At}$ \\
\hline rox & + & 4 & B & $\mathrm{C}+$ & $\mathrm{A}+$ & $\mathrm{C}+$ & $\mathrm{A}+$ & $\overline{\mathrm{A}}$ & $\mathrm{A}$ & $\mathrm{F}$ & $\mathrm{F}+$ & $\mathrm{E}$ & $\overline{\mathrm{B}+}$ & $A$ & A \\
\hline [ay & + & $\mathrm{B}$ & $\mathrm{B}+$ & $\bar{E}$ & $\mathrm{D}+$ & $D$ & $\mathrm{~F}+$ & $\mathrm{L}$ & $\mathrm{B}+$ & $\mathrm{D}$ & $\mathrm{D}+$ & dT & A & A & $\mathrm{A}$ \\
\hline & $\mathrm{C}+$ & $\mathrm{A}$ & $\mathrm{A}$ & $\bar{F}$ & $\mathrm{~F}$ & $\mathrm{~F}$ & A & $\mathrm{A}$ & $\mathrm{A}$ & $\mathrm{F}$ & $\mathrm{F}+$ & $\mathrm{E}+$ & $\mathrm{B}+$ & $\mathrm{A}$ & $\overline{\mathrm{A}+}$ \\
\hline asreen & 4 & $\mathrm{~A}+$ & $\mathrm{A}+$ & $\overline{\mathrm{F}}$ & $\mathrm{F}+$ & $\mathrm{C}+$ & B & $\mathrm{B}+$ & $\bar{A}$ & $\overline{\mathrm{C}}$ & $\bar{E}$ & $\mathrm{C}$ & $\mathrm{A}$ & $\mathrm{A}$ & $\overline{A-}$ \\
\hline
\end{tabular}

Tab. 2: Pedagogical instructors' ranking of candidates' practice teaching

The school math coordinator interviewed the candidates for 15 minutes and summed up his impressions in Tab. 3 below.

The school principal obtained additional data about the candidates' participation in social initiatives during their academic studies, such as helping students, volunteering in charitable organizations or organizing seminars, as described in Tab. 4 below. 